\title{
European Criminal Justice and Continental Criminal Law - A Critical Overview
}

\author{
Vico Valentini ${ }^{\star}$
}

\begin{abstract}
Even though an authentic EU Criminal Law does still not exist, there is an alluvial EU Legislation in criminal matters based on the idea of security and war on crime; indeed, this 'fight-logic' contrasts with the offender-centred approach innervating both the continental criminal culture and the continental constitutional laws. It is, however, more alarming that the very same approach is adopted by what is wrongly considered to be the 'European guardian' of liberal and "classic» guarantees. Although the European Court of Human Rights is continually declaring to seek a fair balance between individual rights and collective security, the European judges tend to fail in this respect. Given that the offenders' and the victims' positions radically conflict, to give preference to victims' interests necessarily means reducing the rights of the offender.
\end{abstract}

\section{European criminal justice, right to secure and victim-centred ap- proach: what about the Kernbereich of 'classic' criminal law?}

For the purpose of this article 'European Criminal Justice' means the criminal justice system drawn up by the Court of Strasbourg when called to rule on the violation, on behalf of the State, of fundamental freedoms enshrined in the European Convention on Human Rights and Fundamental Freedoms (ECHR).

The European Convention, even compared to other international covenants on human rights, is particularly 'poor' in criminal provisions'; since, however, the punitive power ontologically affects human rights and basic freedoms, it is obvious that a 'judge of human rights' constantly deals with it, as it is assumed that those rights are conceived not only as a limit to the coercive power, but also as an entity to be protected by the punitive power ${ }^{2}$. In fact, social defense (favor societatis) and respect for fundamental rights (favor rei) are the two conflicting principles which govern, on the basis of delicate balances, all democratic criminal systems ${ }^{3}$.

Even though an authentic EU Criminal Law does still not exist ${ }^{4}$, there is an alluvial EU Legislation in criminal matters based on the idea of security and, therefore, of war on crime ${ }^{5}$; indeed, this 'fight-logic' contrasts with the offender-centred

\footnotetext{
* Dr Vico Valentini, University of Modena and Reggio, Italy

${ }^{1}$ With the exception of Art. 5 (right to liberty and security) and Art. 6 (right to a fair trial), concerning the criminal process, and Art. 7 (no punishment without law) and Art. 3 (prohibition of torture), concerning the substantive criminal law.

${ }^{2}$ See Bestagno, Diritti umani e impunità. Obblighi positivi degli Stati in materia penale, Milano, 2003, $149 \mathrm{ff}$. , $200 \mathrm{f}$.

${ }^{3}$ Vassalli, I principii generali di diritto nell'esperienza penalistica, RIDPP, 1991, $699 \mathrm{ff} ., 704 \mathrm{f}$.

${ }^{4}$ The Treaty of Lisbon has not substantially changed the former "distribution of competences" in criminal matters between the European Union and its, since several "intergovernmental elements" have been introduced/maintained: Mitsilegas, EC Criminal Law, Oxford-Portland, 2009, 7, 13 f., 36 ff., $107 \mathrm{ff}$.
} 
approach (favor libertas, favor rei) innervating both the continental criminal culture and the continental constitutional laws.

It is, however, much more alarming that the very same approach is adopted by what is (wrongly) considered to be the 'European guardian' of liberal guarantees, namely the 'outpost-body' which refuses to embrace a war-logic and intones a 'counterpoint', in each case claiming the respect of habeas corpus and human dignity ${ }^{6}$.

Of course, the conventional machine is triggered by individuals claiming to be victims of a breach of fundamental rights; it is, therefore, an apparatus conceived and 'built' to protect victims and, therefore, inevitably "hypersensitive" to victims.

In fact, in the ECHR system legal interests do not function as criteria that limit resorting to criminal sanctions ${ }^{7}$, but there are, in their place, the fundamental rights of victims requiring positive protection (also) by means of criminal measures.

Thus, from a genetically victim-centred machine one would expect it also protects the offender, since the latter is a potential victim (of the punitive power) as well $^{8}$; however, this almost never happens: despite European judges continually declaring to seek a fair balance between individual rights (protection of offenders from criminal law) and collective security (protection of victims through criminal law), they tend to be unbalanced in respect of the latter; and given that offenders' and victims' positions radically conflict ${ }^{9}$, first during trial ${ }^{10}$, to give preference to victims' interests means reducing the rights of the offender.

\section{The distorsion of the due process model}

In fact, on the basis of a victim-centred interpretation of the ECHR's provisions $^{11}$, the Court of Strasbourg has altered the due process model (adversarial system) and introduced an increasing number of diversions in respect of the inquisitorial system, which "better protects" the victims of crime ${ }^{12}$ by removing them

\footnotetext{
${ }^{5}$ See e. g. Miranda Rodriguez, O Direito Penal europeu emergente, Lisboa, 2008, 120 ff. See also AA. VV., Manifest zur Europäischen Kriminalpolitik, ZIS, 12/2009, $691 \mathrm{ff}$.

${ }^{6}$ Many scholars emphasize the liberal-approach to criminal justice adopted by the European Court of Human Rights: see e. g. Abbadessa, Il "controcanto" della Corte europea dei diritti dell'uomo: l'europeizzazione della garanzia in materia penale, available on www.dirittoegiustiziaonline.it.; Nicosia, Convenzione europea dei diritti dell'uomo e diritto penale, Torino, 2006, 344 ff., 349 ff.; Frowein, The Interaction Between National Protection of Human Rights and the ECtHR,inWolfrum/Deutsch (eds.), The European Court of Human Rights Overwhelmed by Applications: Problems and Possible Solutions, Berlin-Heidelberg, 2009, $51 \mathrm{ff}$.

${ }^{7}$ This is the traditional approach embraced by the continental criminal science: see e. g. Fiandaca/Musco, Diritto penale, PG, , 5th ed., 2008, 15 f. Pulitanó, Obblighi costituzionali di tutela penale?,RIDPP, 1983, 484 ff.; Stortoni, Profili costituzionali della non punibilità, ivi, 1984, $626 \mathrm{ff}$.

${ }^{8}$ García-Pablos de Molina, El rescubrimiento de la victima: victimización secundaria y programa de reparación del daño. La denominada 'victimización terciaria' (el penado come víctima del sistema legal), AA. VV., La victimología, Madrid, 1993, 108 ff.; Landrove Díaz, La moderna victimología, Valencia, 1998, $191 \mathrm{ff}$.

${ }^{9}$ This is the "communicating vases" theory: Subijana Zanzunegui, El principio de protección de las victimas en el orden jurídico penal. Del olvido al reconocimiento, Granada, 2006, $99 \mathrm{f}$.

${ }^{10}$ Martinez Arrieta, La victima en el proceso penal (I), AP, 4/1990, 44; see also Jackson, Justice for all: putting victims at the heart of criminal justice?, JLS, 30/2003, $213 \mathrm{ff}$; Orvis, Balancing criminal victims' and criminal defendants' rights, in Moriarty(eds.), Controversies in Victimology, Cincinnati, 2003, $1 \mathrm{ff} ., 12 \mathrm{ff}$.

${ }^{11}$ See Wolhulter, Olley, Denham, Victimology. Victimisation and Victims' Rights, London-New York, 2009, 126
} 
from experiences of secondary victimization ${ }^{13}$, eliminating the "torture" of crossexamination $^{14}$ and preserving their private and family life.

It could even be said that in the conventional system, there is a presumption of innocence 'cohabiting' with a (conflicting) presumption in favour of the victim ${ }^{15}$; and it is obvious that conducting a trial on the assumption that there is a victim means assuming that there is a culprit, not an innocent.

In short, the Court infers from Articles 2 (right to life), 3 (prohibition of torture) and 8 (respect for private and family life) ECHR a "statute of procedural rights of the victim-witness" prevailing over the right to fair trial ex Article 6. For example, the European Court has made deeper restrictions on the right to confrontation of the accused when the need to protect the victims emerges ${ }^{16}$, especially when particularly vulnerable ${ }^{17}$. It is important to note, however, that according to the judges of Strasbourg, the "victims" are not only the people offended (or damaged) by the offender, but also all those who, because of the trial, may become victims of a crime $^{18}$; hence, the possible impairment of the right to confrontation when it becomes necessary to protect "witnesses", i. e. all those who make 'useful' statements towards the decision-making process: undercover police officers and drug users, for example, but also accomplices ${ }^{19}$ or convicted people ${ }^{20}$. In short: all the virtual victims (often far from innocent and vulnerable) of the process. As such, in respect of the anonymous testimony, the Court considers it permissible whenever there are "sufficient reasons" (inferred from the nature of the offense, from the "underworld" in which the alleged offender is involved, or even from his/her "fame") for fear of reprisal by the accused ${ }^{21}$.

\section{The imposition of a multi-level duty to take action}

The Court has imposed positive obligations on all institutional bodies to protect the fundamental rights of victims (also) by means of criminal law: the lawmaker is obliged to provide concretely dissuasive punishments ${ }^{22}$ and procedural rules that are

\footnotetext{
${ }^{12}$ About the inconsistency between due process model and protection of victims' interests see Ellison, The adversarial process and the vurnerable witness, Oxford, 2001, 7 ff.; Roach, Due process and victims' rights. The new law and politics of criminal justice, Toronto-Buffalo-London, 1999, $103 \mathrm{ff}$.;Pizzi, Perron, Crime victims in German courtroom: a comparative perspective on American problems,Stanford Journal Int. Law,1996, $37 \mathrm{ff}$.

${ }^{13}$ See Baca Baldomero, Echeburúa Odriozola, Tamarit Sumalla (eds.), Manual de victimología, Valencia, 2006, $32 \mathrm{ff}$.

${ }^{14}$ According to the opinion of Londono, Positive obligations, criminal procedure and rape cases, EHRLR, 2007, $159 \mathrm{ff}$., the crossexamination of the victim-witness can violate the Art. 3 ECHR.

${ }^{15}$ On the conflict between presumption of innocence and presumption in favour of the victim, Seelmann, Dogmatik und Politik der "Wiederentdeckung des Opfers", Schmidt (cur.), Rechtsdogmatik und Rechtspolitik, Berlin, 1990, $167 \mathrm{ff}$.

${ }^{16}$ On the 'weak-dimension' of the right to confrontation adopted by the European Court, see Ubertis, Principi di procedura penale europea, Milano, 2000, $52 \mathrm{ff}$.; Aprile, Diritto processuale penale europeo e internazionale, Padova, 2007, $185 \mathrm{ff} ., 192 \mathrm{ff}$.

${ }^{17}$ SN v. Sweden, 2 July 2002 , available on www.echr.coe.int.

${ }^{18}$ Camilleri v. Malta, 16 March 2000, Cass. pen., 2002, $1815 \mathrm{ff}$.

19 Lucà v. Italy, 27 February 2001, on www.echr.coe.int.

${ }^{20}$ Birutis v. Lithuania, 28 March. 2002, on www.echr.coe.int.

${ }^{21}$ See Balsamo/Recchione, La protezione della persona offesa fra Corte Europea, Corte di Giustizia delle Comunità Europee e carenze del nostro ordinamento, in Balsamo/Kostoris (eds.), Giurisprudenza europea e processo penale italiano, Torino, 2008, $309 \mathrm{ff}$.
} 
"easy to implement" ${ }^{23}$; investigators and prosecutors are obliged to conduct effective, impartial, diligent and complete investigations (s.c. procedural duties) ${ }^{24}$ state agents (military, security forces, police, social workers) are obliged to arrange and take all measures necessary to prevent damage to fundamental rights ${ }^{25}$, and this is when these agents are actually aware of the threat ${ }^{26}$ and when they could reasonably foresee $\mathrm{it}^{27}$; and, finally, the judges, burdened with the obligation to give up 'outdated' positions of equidistance and to punish the violation of fundamental freedoms by means of an anti-indulgent interpretation of criminal law ${ }^{28}$. The European Court, therefore, requires that all State-actors employ a positive activity directed towards the prevention of offences to human rights.

The lawmaker must ensure its reactions are capable of deterring potential offenders; the investigators have to investigate in an insightful and comprehensive way, and judges should interpret criminal law "in a punitive manner", so that the culprits "don't escape" punishment ${ }^{29}$ and, therefore, criminal threat obtains credibility ${ }^{30}$; finally, preventive obligations are also imposed on state agents.

Of course, it would be impossible even to imagine a multi-level "duty to prevent crimes", if this does not correspond to a right to "protection by preventing crimes" claimed by those who are potentially exposed to criminal behaviours: an authentic, autonomous and autonomously justiciable right to protection from potential victimisation (Recht auf Sicherheit, droit à la sécurité) bestowed upon all potential victims of a crime ${ }^{31}$.

Just as in the scenarios that part of the constitutional doctrine theorizes ${ }^{32}$, in fact, the European judges depart from the concept of Bürger als potentielle Opfer to develop a fundamental right to secure capable of disrupting the traditional paradigms of criminal law, which becomes an invaluable ally (Verbündete) in the fight

\footnotetext{
22 Osman v. UK, 28 October 1998, JCP, I, 1999, $105 \mathrm{ff}$.

${ }^{23}$ Perk and others v. UK, 28 March 2006, available on www.echr.coe.int, $\S 54$; see also the "leading case" Xe Y v. The Netherlands, 26 March 1985, RDI, 1987, $147 \mathrm{ff}$.

${ }^{24}$ See Mowbray, The development of positive obligations under the European Convention on human rights by the European Court of human rights, Oxford-Portland, 2004, $211 \mathrm{ff}$; Mowbray, Cases and materials on the European Convention of Human Rights, $2^{\text {nd }}$ ed., Oxford 2007, 25, 100, 115 f., 125. See also Yasa v. Turkey, 2 September 1998, Reports, 1998-VI, $2431 \mathrm{ff}$.

25 Osman v. UK, § 115.

${ }^{26}$ See e. g. Akkoç vs Turkey, 10 October 2000, Recueil, 2000-X, and Kiliç v. Turkey, 28 March 2000, Recueil, 2000III.

${ }^{27}$ Edwards v. UK, 14 March2002, www.echr.coe.int; Mcann v. UK, 27 September 1995, Série A n. 324; Ergi v. Turchia, 28 July 1998, Recueil, 1998-IV

${ }^{28}$ Logemann, Grenzen der Menschenrechte in demokratischen Gesellschaft, Baden-Baden, 2004, 118 ff., 120.

${ }^{29}$ Kelly and others v. UK, 4 May 2001, Recueil, 2001-III, § 96.

${ }^{30}$ Osman v. UK, § 115; Mahmut Kaya v. Turkey, 28 March 2000, www.echr.coe.int, § 85.

${ }^{31}$ Robbers, Sicherheit als Menschenrecht, Baden-Baden, 1987, $13 \mathrm{ff} ., 25 \mathrm{f} ., 144 \mathrm{ff}$. As to the «droit à la sécurité pour l'integrité physique et psychique de la personne, qui fonde le droit eropéen des victimes», see Lanthiez, La clarification des fondements européens des droits des victimes; Giudicelli-Delage/Lazerges (eds.), La victime sur la scène pénale en Europe, Paris, 2008, 145 ff., 154; Doak, Victim's rights, Human Rights and Criminal Justice.Reconceiving the Role of Third Parties, Oxford-Portland, 2008, $38 \mathrm{ff}$., $50 \mathrm{f}$.

${ }^{32}$ Isensee, Das Grundrecht auf Sicherheit. Zu den Schutzpflichten des freiheitlichen Verfassungsstaates, Berlin-New York, 1983, $21 \mathrm{ff}$; id., Leben gegen Leben. Das grundrechtliche Dilemma des Terrorangriffs mit gekapertem Passagierflugzeug, in FS Jakobs, 2007, 205 ff.; Gemma, Diritti costituzionali e diritto penale: un rapporto da ridefinire, Diritto e società, 1986, 459 ff.; see also Dietze, Two concepts of the Rule of Law, Indianapolis, 1973, $53 \mathrm{ff}$.
} 
against the "criminal risk and fear",33. In other words such a criminal justice system may be characterised as "opferorientiert" and - thus - also "sicherheitsorientiert", i. e. it is a system that aims to implement and make effective the right to secure-protection of the "community of potential victims" by neutralizing the risk as well as the fear of crime (Verbrechensfurcht $)^{34}$. Thus, besides the duty of States to prevent and punish all possible attacks against the right to life, indisputable "Roi des Droits"35, or violations of the prohibition of torture under Article 3 ECHR, the Court identifies an independent right of virtual victims to secure against risks threatening life and physical-psychological integrity. Still, à côté of the duty of the State to intervene positively to protect by preventing "less fundamental" freedoms (e.g. the right to respect for private and family life, the freedom of religion, the freedom of association, and so on), the Court identifies a perfect right to the neutralization of all risks incumbent on those freedoms ${ }^{36}$. Europe, in short, solves the age-old controversy between individual and collective guarantees in favour of the latter, obliging the State apparatus to embrace a logic significantly different from the one imposed by the principle of subsidiarity and extrema-ratio.

\section{The manipulation of 'classic' purposes of criminal punishment}

The Court has manipulated the 'classic' and liberal purposes of criminal punishment, granting a preeminent position to concrete victims as well (tatsächlichen Verbrechensopfer): just as potential victims have a right to secure and protection from all offences, according to the Court, concrete victims have a real interest in the punishment of the offender ${ }^{37}$.

Hence, the 'bulky' presence of the so called third party even at the time of sentencing ${ }^{38}$; indeed, the purposes of criminal punishment "oriented to Europe" are only the function of deterrence (which looks at the virtual victims, since it discourages potential offenders), and the restorative-compensation function ${ }^{39}$ (which looks at the concrete victims, their moral satisfaction and their need for punishment as a response to the "denial of justice") 40 .

This second purpose is very similar to that proposed by the neo-retributive theory of criminal punishment; and just like this theory, 'European punishment' is openly uninterested in the offender: indeed, in very rare cases in which the judges

\footnotetext{
${ }^{33}$ Hassemer/Reemtsma, Verbrechensopfer. Gesetz und Gerechtigkeit, München, 2002, $29 \mathrm{ff}, 60 \mathrm{ff}$.

${ }^{34}$ Hassemer/Reemtsma, Verbrechensopfer, 110; Donini, Sicurezza e diritto penale, Cass. pen., 2008, $3558 \mathrm{ff}$. On the linkage between Bürger-potentielle Opfer - Grundrecht auf Sicherheit - statlichen Schutzflichten, see BURGI, Vom Grundrecht auf Sicherheit zum Grundrecht auf Opferschutz, in FS Isensee, 2007, $655 \mathrm{ff}$. As to the subiektive Sicherheitsgefühl als schützenswertes Rechtsgut, see Meyer, Die Beeinträchtigung des subiektiven Sicherheitsgefühl als polizeiliche Gefahr?, in Arndt et al (eds.), Freiheit-Sicherheit-Öffentlichkeit, Baden-Baden, 2009, $111 \mathrm{ff}$.

35 Sudre et al., Les grands arrêts de la Cour européenne des Droits de l'Homme, $4^{\text {th }}$ ed., Paris, 2007, 104.

${ }^{36}$ DOAK, Victims' rights, $37 \mathrm{ff}$.

${ }^{37}$ On this approach, see Reemtsma, Das Recht des Opfers auf Bestrafung des Täters - als Problem, München, 1999.

${ }^{38}$ See the critical view of Hörnle, Die Rolle des Opfers in der Straftheorie und im materiellen Strafrecht, JZ, 2006, $950 \mathrm{ff}$.

${ }^{39}$ Welsch v. UK, 9 February 1995, S. A, n. 307, § 30.

${ }^{40}$ Bestagno, Diritti umani, $201 \mathrm{ff} ., 209 \mathrm{ff}$.
} 
of Strasbourg assign to the criminal penalty even a function of positive special prevention, it has only secondary importance compared to the need of moral satisfaction and social defence ${ }^{41}$. 'European punishment', therefore, only looks at the victims and considers the virtual criminal as a subject to intimidate and disable by exemplary penalties, not as someone who should be reintegrated into society.

\section{The other principle of legality in criminal law}

Above all, the European Court has re-handled the Kernbereich of criminal law, rereading in a victim-centred manner even what remains of criminal law as 'Magna Charta' of the offender: the principle of legality and its ramifications ${ }^{42}$. The point is crucial and complex and, therefore, deserves a little deeper reflection. The ECHR system, having to 'dialogue' with the common law systems as well, had to embrace a material-substantial concept of legality ${ }^{43}$ : European human rights law, in fact, does not provide the monopoly of national Parliament over criminal matters. In other words, criminal offences and punitive sanctions could be provided by sub-primary sources, supranational sources and even unwritten sources, such as case-law (including national) and customary law (even international) ${ }^{44}$. In this context, therefore, the judges also may create offences, i. e. they are authentic sources of criminal law ${ }^{45}$. It is quite obvious that such a notion of legality, if aiming to (continue to) protect the "sécurité juridique» of citizens against punitive power ${ }^{46}$, must emphasize the material features of law (written and unwritten) ${ }^{47}$, claiming that it complies with several quality contents; hence, the need for accessible and predictable crimes and punishments, both through the contribution of the lawmaker in addition to that of the judge. In short: the 'portion' of predictability-foreseeability 'lost' because of the multiplication of sources ${ }^{48}$, is counter-balanced by an "obligation général de prévisibilité» of the conviction ${ }^{49}$ that involves both the written (lawmaker) and the unwritten (judge) law. In particular, this 'general obligation' can be considered from both a synchronic and diachronic point of view. Let's start with the latter.

\footnotetext{
${ }^{41}$ On the purposes of punishment in the ECHR system see Bestagno, Diritti umani, $202 \mathrm{f}$., $213 \mathrm{f}$.

42 As to the principle of legality and its sub-principles (clear definition, non-retroactivity and prohibition of reasoning by analogy) as Magna Charta des Verbrechers, see e. g. Schönke/Schröder, Strafgesetzbuch Kommentar, $28^{\text {th }}$ ed., München, 2010, $26 \mathrm{f}$. Even if criminal law cannot be considered as a "Magna Charta" of the offender anymore (nicht mehr in dem Sinne als Magna Charta des Verbrechers), the principle of legality preserves its nature of Schutznorm für den Täter: Jeschek/Weigend, Lehrbuch des Strafrechts, AT, $5^{\text {th }}$ ed., Berlin, 1996, 138, 140.

${ }^{43}$ Sudre, Droit européen et international des droits de l'homme, $8^{\text {th }}$ ed., Paris, 2006, 422.

${ }_{44}$ Chiavario, La Convenzione europea dei diritti dell'uomo nel sistema delle fonti normative in materia penale, Milano, 1969, $89 \mathrm{ff}$.

${ }^{45}$ See Rolland, sub art. 7, in Pettiti/Decaux/Imbert (eds.), La Convention européenne des droits de l'homme. Commentaire article par article, Paris, 1999, 293 ff., 294. See also infra, iv.3.

${ }^{46}$ Gragnic v. France, 12 April 1995, § 61, available on www.echr.coe.int.

${ }^{47}$ Delmas Marthy, Fécondité des logiques juridiques sous-jacentes;, id. (eds.), Raisonner la raison d'Etat, Paris, 1989, $471 \mathrm{ff}$.

${ }^{48}$ Esposito, Il diritto penale "flessibile". Quando i diritti umani incontrano i sistemi penali, Torino, 2008, $322 \mathrm{ff}$.

${ }^{49}$ Rolland, sub art. 7, 295.
} 


\section{a) A fuzzy prohibition of retroactivity}

From a diachronic point of view, the general constraint of predictability is divided into a double prohibition: the Parliament cannot pass retrospective criminal legisla$\operatorname{tion}^{50}$; the judges, as a general rule, are not allowed to depart from the constant and well-established interpretation that the provision was receiving at the time of the conduct, whenever this reversal redounds to the detriment of the accused ${ }^{51}$. Therefore, contrary to what happens in continental criminal justice systems (in which the rule of non-retroactivity does not bind the judges "in a strong manner" $)^{52}$, in the ECHR system the rule also 'catches' the judicial interpretation ${ }^{53}$. The ECHR law, therefore, seems to extend the range of protected reliance (Vertrauensschutz) and amplifies the protection of the right of self-determination, since it prohibits both the legislative ('expressed') and the judicial ('occult') retroactivity. In fact, the "European non-retroactivity" is regarded by many Italian scholars as an ideal model "to import" ${ }^{34}$; but if those scholars consider the way in which that model is carried out, it is highly probable they would change their mind.

Apart from the finding that the supranational system, unlike the domestic system $^{55}$, considers the principle derogable ${ }^{56}$, to raise more than a doubt is the

${ }^{50}$ The principle of non-retroactivity under Art. 7 ECHR concerns both the offence and the punishment: see Gomien/Harris/Zwaak, Law and practice of the European Convention on Human Rights and the European Social Charter, Strasbourg, 1996, $203 \mathrm{ff}$.

${ }^{51}$ See e. g. Comm., Ekelmann v. Switzerland, 4 March 1985, DR41, 181 f.; Comm., X v. Austria, 12 March 1981, DR22, $140 \mathrm{ff}$. On this point, see also Pradel/Corstens, Droit pénal européen, $2^{\text {nd }}$ ed., Paris, 2002, $340 \mathrm{f}$.

${ }^{52}$ Lackner/Kühl, sub $\$ 1$, Stafgesetzbuch Kommentar, $26^{\text {th }}$ ed., München, 2007, 10; Kindhäuser/Neumann/Paeffen (eds.), Strafgesetzbuch Kommentar, $2^{\text {nd }}$ ed.,I, Baden-Baden, 2005, $164 \mathrm{f}$. See also Wessels/Beulke, Strafrecht, AT, $39^{\text {th }}$ ed., , Heidelberg, 2009, 12 f.; Kindhäuser, Strafrecht, AT, $4^{\text {th }}$ ed., Baden-Baden, 2009, 41.

${ }^{53}$ See Comm., Crociani and others v. Italy, 18 December 1980, DR22, 173.

${ }^{54}$ See e.g. Bernardi, Nessuna pena senza legge (art. 7); Bartole/Conforti/Raimondi, (eds.), Commentario alla Convenzione Europea per la tutela dei diritti dell'uomo e delle libertà fondamentali, Padova, 2001, 249 ff., 252 ff.; Rionato, Retroattività del mutamento penale giusrisprudenziale sfavorevole, fra legalità e ragionevolezza, AA. VV., Diritto e clinica per l'analisi della decisione del caso, Padova, 2000, $239 \mathrm{ff}$.

55 The principle of non-retroactivity, within the continental criminal justice systems, has always been considered as an unconditional and absolute principle that can never be derogated: see Bricola, Legalità e crisi: $1^{\prime}$ art. $25,2^{\circ}$ e $3^{\circ}$ co, della Costituzione rivisitato alla fine degli anni 70,QG, 1980, $179 \mathrm{ff}$.; Pagliaro, Principi di Diritto penale, $8^{\text {th }}$ ed., Milano, 2003, 115 ff.; Kre , Keine Strafe ohne Gesetz. Einführung in die Dogmengeschichte des Satzes "nullum crimen, nulla poena sine lege“" Berlin-New York, 1983, 103 ff.; Satzger/Schmidt/Widmaier (eds.), sub § 2, Abs. 2, StGB Kommentar, Köln, 2009, 26; Muñoz Conde/García Arán, Derecho penal, $6^{\text {th }}$ ed., Valencia, 2004, 140 f.; Pradel, Droit pénal général, Paris, 2006, $128 \mathrm{fff}$. On the substantial validity of the "continental non-retroactivity" see also Alexy, Der Beschluss des Bundesverfassungsgericht zu den Tötungen an der innerdeutschen Grenze vom 24. Oktober1996, Hamburg, 1997, 19.

${ }^{56}$ Contrary to what is established by Art. 15 ECHR, stated by the Court (eg. CR v. UK, 22 November 1995, RIDU, 1996, 184 ff., § 32) and affirmed by many scholars (eg. Jacobs/White, The European Convention on human rights, $2^{\text {nd }}$ ed.,Oxford, 1996, 162; Dannecker, Das intertemporale Strafrecht, Tübingen, 1993, 152), it is quite clear that the «European non-retroactivity» can be derogated (Art. 7 par. 2 ECHR): van Dijk/van Hoof/van Rijn/Zwaak (cur.), Theory and practice of the European ConventiononHuman Rights, $4^{\text {th }}$ ed., Oxford, 2006, 651 ff, 662. In other words, it is clear that the clause ex Art. 7, par. 2, is an authentic exception to the rule ex Art. 7, par. 1. Indeed, the only way to assert that the «Nuremberg clause» is «superflous» (Satzger, Internationales und Europäische Strafrecht, $3^{\text {rd }}$ ed., Baden-Baden, 2009, 211) and "flowery» (Cameron, An introduction to the European Convention on human rights, $5^{\text {th }}$ ed., Uppsala, 2006, $101 \mathrm{ff}$.), is to strech the meaning of the text, considering that the crimes «according to the general principles of law recognised by civilised nations» are only the "crimes against international law» (genocide, aggression, crimes against humanity and war crimes), which can already be (retrospectively) punished under Art. 7 par. 1 ECHR: A Cassese, Balancing the prosecution of crimes against humanity and non-retroactivity of criminallaw, JICJ, 2006, $410 \mathrm{ff}$. In our opinion, the «Nuremberg clause» allows retrospective punishment of behaviors much more 
parameter that the Court has arranged for testing its violation "by the judge's interpretation". The European Court, in absolute truth, never said that when a judge moves away from the constant, established and more favourable interpretation practiced at the time of the conduct, he or she goes beyond the mere clarificationadaptation of criminal law, that (as such) is reasonably predictable ${ }^{57}$.

Quite the contrary: the Court has repeatedly endorsed authentic reversals, considering them to be in conformity with the principle of non-retroactivity because of their "reasonable foreseeability".

It is, of course, one thing to say outright that the principle prohibits a court to opt for a different and less favourable interpretation than that which was in force at the time of the conduct (connecting to this 'deviation' an absolute presumption of unpredictability); quite another thing, however, is to say that the principle is violated only when this reversal was not reasonably foreseeable.

In the latter case, it is clear that the real and concrete range of application of the intertemporal rule entirely depends on the "ontological basis" of the "reasonable foreseeability assessment", i. e. it depends on how many (number) and what (type) are the elements that will be used to check whether the interpretation solution was, or was not, predictable.

Therein lies the point: the judges of Strasbourg usually include in the "ontological basis" of assessment of foreseeability, along with legal-normative ingredients 58 , vague and volatile elements inferred from the cultural and socio-political context (eg. initiatives and parliamentary debates, cultural progress, evolution of social consciousness etc. $)^{59}$, even going as far as to say that a reversal contra reum is reasonably foreseeable if it is consistent with the modern society ${ }^{60}$ and, therefore, with the modern-day criminal justice ${ }^{61}$.

It is quite obvious that everything becomes predictable through these parameters.

This explains why the Court has never invoked the exception ex art. 7, par.. 2, ECHR beyond the crimes related to World War II: since it has arranged an assessment of reasonable predictability able to save any interpretation.

The four leading cases of (macroscopic) occult retroactivity are well-known; two cases relate to ordinary crimes that occurred in a 'normal' context, while the other two cases concern 'systemic wrongdoings' ${ }^{62}$ related to the 'abnormal' context of the

«normal» than the gross violations: see also Werle, Rückwirkungsverbot und Staatkriminalität,NJW, 2001, $3001 \mathrm{ff}$., 3006 .

${ }^{57}$ Jacobs/White, The European Convention on human rights, $4^{\text {th }}$ ed., Oxford, 2006, 215; see also C.R. v. UK, § 39

${ }^{58}$ Case law and practices; clarity-vagueness in legal texts; accessibility of law, etc.

${ }^{59}$ CR v. UK, $\S \S 35 \mathrm{ff}$.

${ }^{60}$ CR v. UK, \& 42.

${ }^{61}$ Schermers, General Course on the European Convention on Human Rights, AA. VV., Collected courses of the Academy of European Law, VII, 2, The protection of human rights in Europe, The Hague-Boston-London, 1996, $1 \mathrm{ff} ., 38$, also emphasizes that the European Court interprets the ECHR's provisions «in the context of our present time».

${ }^{62}$ On the concept see Naucke, Die stafjuristische Privilegiurung staatveverstärkter Kriminalität, Frankfurt a. M., 1996; id., Bürgerliche Kriminalität, Staatskriminalität und Rückwirkungsverbot, in FS Trechsel, 2002, 505 ff.; Lampe, Systemunrecht und Unrechtssysteme, ZStW, 1994, 683 ff.; Lüderssen, Der Staat geht unter - das Unrecht bleibt?. Regierungskriminalität in der ehemalingen DDR, $6^{\text {th }}$ ed., Frankfurt a. M., 1992; Teitel, Transitional justice, Oxford, 
German transition ${ }^{63}$. In the first two cases $^{64}$, the Court declared the reasonable predictability of an authentic overruling, since it endorsed a conviction for attempt of rape in which the English courts for the first time denied the application of the marital immunity, namely a cause of non-punishability undoubtedly in force at the time of the conduct ${ }^{65}$. Within seconds, the Court ratified the conviction of three political leaders and a border-guard (Mauerschütze) of the GDR former regime ${ }^{66}$, by considering the re-interpretation "friend of human rights" (menschenrechtsfreundlich) of Articles 213 of the GDR Criminal Code, 27 of the GDR Border Statute (Grenzgesetz) as legitimate and, in particular, not in conflict with the principle of non-retroactivity. The European Court did not invoke the 'Nuremberg clause' (Art. 7 par. 2 ECHR) in any of the four decisions, arguing that the (re)-interpretatio abrogans and the "menschenrechtsfreundliche" interpretation were "reasonably foreseeable" (and, therefore, complied with the rule ex art. 7 par. 1 ECHR).

When, therefore, does the case arise that a change in interpretation is consistent with the criminal justice system 'of modern times' and, as such, is reasonably foreseeable? What does 'modern society' mean?

The 'modern-day criminal law', in the opinion of the Court, is the criminal justice system that considers 'criminal' - and punishes all - violations of European Human Rights Law: it is enough that a behaviour is barbaric and heinous, namely in conflict with fundamental rights, to make it intolerable.

From the Court's perspective, therefore, there is no need for a victim of crime: whenever there is a victim of 'non-conventional crime' (i.e. a victim of a conduct that does not constitute a crime under national or international criminal law, but violates the European Human Rights Law) ${ }^{67}$, it could be possible to punish retro-

2000, 33 ff.; Jakobs, Untaten des Staates - Unrecht im Staat. Strafe für die Tötungen an der Grenze der ehemaligen DDR?, GA, 1994, $1 \mathrm{ff}$.

${ }^{63}$ As to the German transition to rule of law see e. g. Marxen-Werle, Die strafrechtliche Aufarbeitung von DDRUnrecht. Eine Bilanz, Berlin, 1999, 141 ff.; Werle (eds.), Justice in transition - Prosecution and amnesty in German and South Africa, Berlin, 2006; Jakobs, Vergangenheitsbewältigung durch Strafrecht? Zur Leistungsfähigkeit des Strafrechts nach einem politischen Umbruch, Isensee (ed.), Vergangenheitsbewältigung durch Strafrecht, Berlin, 1992, 37 ff.; Rommler, Die Gewalttaten an der deutsch-deutschen Grenze vor Gericht, Berlin, 2000; Polakiewicz, Verfassungund völkerrechtliche Aspekte der strafrechtliche Ahndung des Schusswaffeneinsatzes ad der innerdeutschen Grenze, EuGRZ,, 1992, 177 ff.; Hirsch, Rechtsstaatliche Strafrecht und staatlich gesteuertes Unrecht, Düsseldorf, 1996; F. Herzog, Zur strafrechtlichen Verantwortlichkeit von Todesschützen an der innerdeutschen Grenze, NJ, 1993, 1 ff.; Schreiber, Die Strafrechtliche Aufarbeitung vom staatlich gesteuerten Unrecht, ZStW, 1995, 157 ff.; Dannecker, Die Schüsse an der innerdeutschen Grenze in der höchstrichterlichen Rechtsprechung, Jura, 1994, 585 ff.; Häberle, Diskussionbeitrag, VVDStRL, 1992, 117 ff.; Buchner, Die Rechtswidrigkeit der Taten von "Mauerschützen im Lichte von Art. 103 II GG unter besonderer Berücksichtigung des Völkerrechts. Ein Beitrag Problem der Verfolgung von staatlich legitimierten Unrecht nach Beseitigung des Unrechtssystems, Frankfurt a. M., 1996. See also Brunner (ed.), Juristische Bewältigung des Kommunistischen Unrecht in Osteuropa und Deutschland, Berlin, 1995; and Vassalli, Formula di Radbruch e diritto penale. Note sulla punizione dei "delitti di Stato" nella Germania postnazista e nella Germania postcomunista, Milano, 2004, $109 \mathrm{ff}$. On the ab-normality of the transitional criminal justice, see Valentini, Justicia penal transicional y justicia penal europea. El protagonismo de las víctimas y la renuncia al derecho penal liberal, NFP, 76/2011, Medellín (in press).

${ }^{64}$ S.W. vs.UK, 22 November 1995, on www.echr.coe.int.

${ }^{65}$ According to an ancient commom law principle, an husband could not be found guilty of rape; this unwritten

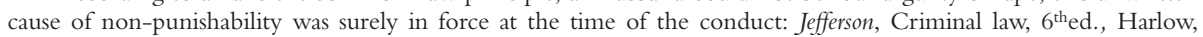
2003, 4; Card/Cross/Jones, Criminallaw, 6 $6^{\text {th }}$ ed., London-Edinburgh, 2004, 18; Juratowitch, Retroactivity and the Common Law, Oxford-Portland, 2008, $129 \mathrm{ff}$.

${ }^{66}$ GC, Streletz, Kessler, Krenz e K-H. W. v. Germany, 22 March 2001, on www.echr.coe.int 
actively (on the basis of the exception ex Art. 7 par. 2 ECHR) ${ }^{68}$, as well as to consider the conviction as reasonably foreseeable (namely, in compliance with the rule ex Art. 7 par. 1 ECHR).

According to the European Court, therefore, whatever violates the conventional rights could be punishable; it is therefore superfluous to examine whether the conduct, at the time when it was committed, was or was not provided for by criminal legislation. As such, and in reference to the marital-rape cases, it is sufficient to verify that the conduct is in contrast to the purposes of the Convention, while it is not necessary to determine whether the facts were or were not covered by the cause of non-punishability: "[..] the abandonment of the unacceptable idea of an husband being immune against prosecution for rape of his wife was in conformity not only with the civilised concept of marriage but also, and above all, with the fundamental objectives of the Convention, the very essence of which is respect for human dignity and human freedom" "69; for these reasons, the Court "does not find necessary to enquire whether the facts in the applicant's case were covered" by the marital immunity ${ }^{70}$. Obviously, if this assumption is valid for 'normal' crimes, then it will be even more valid for 'systemic and abnormal' crimes; in the case of the Mauerschützen, in fact, the European Court endorsed the conviction by radically asserting that the former State practice of the GDR flagrantly violated fundamental rights and, therefore, cannot be protected by the Art. 7 par. 1 ECHR. This practice, in other words, cannot be considered as "law" under the European Convention" ${ }^{71}$.

\section{b) The implicit legitimation of reasoning by analogy}

From the static point of view, this constraint of predictability consists of the obligation of clarity and precision (incumbent on lawmakers: see below lit. c) on the one hand and the obligation of strict interpretation (incumbent on judges) ${ }^{72}$ on the other hand. If I preferred to talk about strict interpretation (or prohibition of extensive interpretation to the accused's detriment) ${ }^{73}$ rather than prohibition of reasoning by analogy, there is a precise reason for this: the judges of Strasbourg, in fact, consider the analogy to be a mere kind (species) of extensive interpretation ${ }^{74}$. In other words, according to the Court, it is not important to verify whether or not a judge has reasoned analogically; what is important, however, is to verify whether this extension or authentic creation was "reasonably foreseeable",75.

The duty of strict interpretation/prohibition of analogy, as well as the retroactivity guarantee, is therefore reconstructed "in a subjective manner" (having

\footnotetext{
${ }^{67}$ On the concept of victims of non-conventional crime, see SubijanaZunzunegui, El principio, $20 \mathrm{f}$.

${ }^{68}$ See van Dijk/van Hoof, Theory and practice of the European Convention on Human Rights, $3^{\text {rd }}$ ed., The Hague-London-Boston, 1998, $366 \mathrm{f}$.

${ }^{69}$ CR v. UK, $\$ 42$.

${ }^{70}$ CR v. UK, \$ 43 .

71 GC, Streletz, Kessler, Krenz e K-H. W. v. Germany, § 7.

$72 \mathrm{Pradel} /$ Corstens, Droit pénal européen, $338 \mathrm{ff}$.

${ }^{73}$ CR v. UK, § 33

${ }^{74}$ Eposito, Il diritto, $327 \mathrm{f}$.

${ }^{75}$ See Rolland, sub art. 7, 299.
} 
regard to the expectations of citizens/virtual offenders), rather than "in an objective manner" (distinguishing "impersonally" between the concepts of analogy and extensive interpretation) ${ }^{76}$. That is the reason why, more than a requirement of strict interpretation, it is preferable to speak of requirement of (even analogical, but) foreseeable interpretation.

The fact that the Court minimizes the distinction between analogy and extensive interpretation seems to boost the protection of the citizen/virtual offender, as a breach of the Convention will occur even when the judge, without exceeding the possible meanings of a legal text (extensive interpretation consistent with the 'continental' principle of legality), leads to an unforeseeable result.

The problem, however, is that the opposite is also true: in this way, in fact, the reasoning by analogy ceases to be prohibited and unlawful, since it becomes feasible whenever the punishment of (anti-social, but) lawful behaviours was reasonably foreseeable; and, as mentioned earlier, it happens when a conduct conflicts with the objectives of the Convention and violates the principle of human rights protection. In conclusion: first, the Court states that criminal law should not be interpreted broadly or analogically to the accused's detriment, and then, however, it endorses extensive/analogical interpretations of crimes (or restrictive/abrogating interpretations of defence) whenever it is necessary to secure, restore and compensate the victims of a violation of fundamental rights.

\section{c) The blurred version of the principle of clarity}

Finally, the judges of Strasbourg embrace a very fuzzy and blurred version of the principle of clarity, as they more or less explicitly urge the lawmaker to prefer general terms rather than detailed descriptions; from the point of view of the Court, in fact, the vagueness of legal texts is indispensable to adapt criminal offences to new circumstances $^{77}$ through the "complementary-supplementary action" of judges ${ }^{78}$.

\section{The structural fluidity of the conventional system}

It should be specified, to avoid any doubt, that such solutions are fully consistent with the structure of the ECHR system, in which there are no legal rules but only legal principles ${ }^{79}$ : that system, in fact, is based on the "consistency clause" ex Art. 17 ECHR (abus de droit), according to which a right recognized by the Convention cannot be invoked to justify an action or activity aimed at the destruction of other conventional rights.

\footnotetext{
${ }^{76}$ Ambos, Principios e imputación en el derecho penal internacional, Barcelona, 2008, $35 \mathrm{ff} ., 43 \mathrm{f}$.

77 Cantoni v. France, 15. 11. 1996, RIDU, 1997, 110 ff., § 31; E.K. v. Turkey, 7 February 2002, on www.echr.coe. int, $\S 52$. See also Berger, Jurisprudence de la Cour européenne des droits de l'homme, Paris, 2007, $374 \mathrm{ff}$.

${ }^{78}$ Comm., X Ltd. and Yv. UK,DR28, 86. See also Cameron, An introduction, $101 \mathrm{f}$.

${ }^{79} \mathrm{On}$ the distinction between elastic principles and anelastic rules, see Guastini, Teoria e dogmatica delle fonti, Milano, 1998, $275 \mathrm{ff}$.
} 
First of all, this means that a conventional right automatically loses its "power to resist" (substantial validity) where its exercise involves the violation of other fundamental rights.

Secondly, it also means that conventional rights are not absolute, but can be balanced with other rights of equal rank and, therefore, can succumb to other rights of superior rank ${ }^{80}$.

It is quite natural that the guarantees of criminal law are also involved in this 'fluidity', but the problem is that such a criminal justice system is too different from that which is adopted by the continental systems.

And it does not end there.

The method by which the Court decides on the violation of conventional freedoms is also extremely fluid.

The Court's approach, in fact, is holistic, because the situations are evaluated as a whole, without regard to individual aspects; it is multifactorial, because it takes account of all subjects (public and private) ${ }^{81}$ and all the elements (normative, but also factual) involved in those situations ${ }^{82}$; and it is anti-formalistic, since it aims to verify if the situation reported has effectively and concretely violated a conventional right $^{83}$.

With respect to criminal proceedings, for example, the Court considers whether the process as a whole (without dwelling on the individual stages in which it was articulated) was structured and 'managed' by the national bodies (lawmaker, judges, investigators, police) taking into account all the private parties involved (offender, victims, injured) and in a manner that complies with the 'spirit' (i.e. beyond and apart from the 'slavish' observance of procedural forms) of Art. 6, ECHR. Such methodology obviously generates temporary, intuitive and very unpredictable solutions: providing the judge with a vast number of factors and circumstances on which to base the decision and, above all, allowing him or her to re-configure hierarchies and the 'weight' of these factors case by case, can justify any solution ${ }^{84}$.

In particular, such an approach allows judges to freely deform and shape the 'physiognomy' of a system, namely to give way to the interests, positions and persons considered 'dominant'; if, for instance, the mission assigned to criminal law is to protect and satisfy interests conflicting with those of the accused (that is to say of victims), the holistic and multi-factorial re-interpretation will be able to re-

${ }^{80}$ Christoffersen, Fair Balance: Proportionality, Subsidiarity and Primarity in the European Convention on Human Rights, Leiden-Boston, 2009, 83 ff. On the Art. 17 ECHR as Grundrechtsschranke, see also Stieglitz, Allgemeine Lehren im Grundrechtsverständnis nach der EMRK und der Grundrechtsjudikatur des EuGH, Baden-Baden, 2002, $96 \mathrm{f}$.

${ }^{81}$ Lawmaker, judge, offender and victims, public agents and investigators.

${ }^{82}$ See Muzny, La technique de proportionnalité et le juge de la Convetion Européenne des droits de l'homme, Essai sur un instrument nécessaie dans une société démocratique, Aix-en-Provence, 2005; Šušnjar, Proportionality, Fundamental Rights, and Balance of Powers, Leiden-Boston, 2010, $85 \mathrm{ff} ., 173 \mathrm{ff}$.

83 That's the principle of effectiveness: Reid, APractitioner's Guide to the European Convention on Human Rights, $2^{\text {nd }}$ ed., London, 2004, $37 \mathrm{ff}$.

${ }^{84}$ Vogliotti, La logica floue della Corte Europea dei diritti dell'uomo tra tutela del testimone e salvaguardia del contraddittorio: il caso delle «testimonianze anonime», Giur. it., 1998, IV, $851 \mathrm{ff}$.; Letsal, A theory of interpretation of the European Convention of Human Rights, Oxford, 2009, $120 \mathrm{ff}$. 
discuss all the rights of the accused: such rights will tend to "surrender" each time it is necessary to satisfy the counter-interests regarded as 'dominant'.

In light of all the aforementioned reasons, in the author's opinion, it is unrealistic to think we could 'Europeanise' continental criminal law without deforming its 'physiognomy': continental criminal justice and European criminal justice are too different to be aligned.

\section{European 'victim-centrism' and continental 'offender-centrism'}

The purpose of this brief raid on the European criminal justice was to demonstrate its genetic heterogeneity with respect to continental criminal justice; indeed, in the latter, the criminal process is still primarily the 'guardian' of the rights of the accused, who is presumed to be innocent, while substantive law is still mostly 'the Magna Charta' of the offender, i. e. a set of guarantees against the punitive power.

Continental criminal law, in particular, is an (excluding, but also) "humanistic" mechanism, crossed by the principle of culpability; it is therefore designed to 'dialogue' with the offender, and as such is directed at his/her rehabilitation. 'Continental punishment' also fulfils a disabling function, of course, but the principle of personality prohibits exemplary convictions for purposes of deterrence, and forbids that a prognosis of danger 'for the future' may justify disproportionate restrictions 'for the past'.

This does not mean, of course, that some rules are not present, some microsystems designed to neutralize which coexist with the criminal law of culpability and proportionality ${ }^{85}$; and this does not even mean that continental systems do not know a 'preventive criminal justice', since the offender-centred approach can and must be balanced with social defence strategies ${ }^{86}$.

In continental criminal justice, however, the victim continues to be marginalized $^{87}$, and his or her "rights" are still not a constitutional interest "in itself" 88 : the real victim of the criminal system, in other words, continues to be the culprit.

The growth of pro-victim movements and victimology studies, in short, has failed 'to dent' the continental culture's attachment to an offender-centred criminal system, in which the victims are dissolved into the concept of legal interest (Rechtsgut, bien jurídico, bene giuridico).

When the State then releases the punitive monopoly and 're-calls' the concrete victim, his or her intervention always benefits the accused ${ }^{89}$.

\footnotetext{
${ }^{85}$ Donini, Il diritto penale di fronte al «nemico», Cass. pen., 2006, $735 \mathrm{ff}$.

${ }^{86}$ For these reasons, it surprises me a little who defines "original" the European approach, which combines a protection from criminal law with a protection through criminal law: see e.g. Viganò, Il diritto penale sostanziale italiano davanti ai giudici della CEDU, AA. VV., La tutela dei diritti e delle libertà nella CEDU, Giur. merito, 12/ 2008, 81 ss. Indeed, the Risikostrafrecht also aims to protect virtual victims by means of criminal law.

${ }^{87}$ Or neutralized: Kindhäuser/Neumann/Paeffgen (eds.), Vor $§ 1$, StGBKommentar, $2^{\text {nd }}$ ed., I, Baden-Baden, 2005, $81 \mathrm{f}$.

${ }^{88}$ Schünemann, Zur Stellung des Opfers in System des Strafrechtspflege, NStZ, 1986, $197 \mathrm{ff}$.

${ }^{89}$ Just think of the victim-dogmatic and restorative justice: Pérez Cepeda, La victimodogmática en Derecho penal, inReyna Alfaro (ed.), Derecho, proceso penal y victimología, Mendoza, 2003, 59 ff.; Beulke, Opferautonomie im
} 
The process of de-marginalization of the victim ${ }^{90}$, in sum, has been 'calibrated' on the offender-centred features of continental criminal justice, which, by the way, preserves its original identity.

In Europe, by contrast, a new golden age of victims has been resurrected, as third parties are at the centre of the criminal policies (right to secure) as well as at the centre of sentencing (right to punishment) ${ }^{91}$.

If it is true that since the High Middle Ages the vindicatory reaction of the injured by crime is subject to 'public control' in order to avoid a spiral of reciprocal violence $^{92}$; and if it is true that the criminal justice system of the modern State is born with the specific purpose to protect the offender from disproportionate reactions of the "society of victims" 93 on the one hand, and "to domesticate" the criminal-policies, on the other hand ${ }^{94}$; if it is true, in conclusion, that criminal law is an apparatus genetically offender-centred, then it is obvious that when it becomes a system based on the cult of the victim, it becomes necessarily irrational: to draw up victim-oriented criminal policies means losing objectivity, impartiality and proportionality $^{95}$.

What is certain, in particular, is that when criminal justice allies with victims, that is, when the purpose of criminal law is to "bring security" and protect the rights of the victims, it becomes more interventionist (non-subsidiary) and more violent (non-dialogic) against those who threaten or violate those rights.

For these reasons, it is not completely true that the citizens/virtual victims, pervaded by the fear of crime (Verbrechensfurcht), agree to give away a "portion" of their freedom in exchange for a greater safety ${ }^{96}$; on the contrary, a more interventionist and more violent criminal justice system anticipates and, thus, maximizes the protection of these freedoms.

In other words, criminal law does not sacrifice the rights and freedoms of all individuals who make up the social body; it only affects the rights and freedoms of a particular category (offenders) in order to protect all the others (the society of

Strafrecht.Zum Einfluss der Einwilligung auf die Beurteilung dereinverständlichen Fremdgefährdung ,in FS Otto, 2007, 207 ff.; Del Tufo, Profili critici della vittimo-dommatica. Comportamento della vittima e delitto di truffa, Napoli, 1990; Di Giovine, Il contributo della vittimanel delitto colposo, Torino, 2003; Mannozzi (ed.), Mediazione e dirittopenale. Dalla punizione del reo alla composizione con la vittima,Milano, 2004. In both cases, the victim is «used» to enforce the principle of subsidiarity-extrema ratio.

${ }^{90}$ Cancio Meliá, Conducta de la víctima e imputación objetiva en Derecho penal. Estudio sobre lo ámbitos de responsabilidad de víctima y autor en actividades arriesgadas, $2^{\text {nd }}$ ed., Barcelona-Bogotà, 2001.

${ }_{91}$ It also happened in the ancient Roman legal system: Costa Andrade, A vítima e o problema criminal, Coimbra, 1980, 50 ff.; García-Pablos de Molina, La aportación de la victimología: Víctima, criminología, política criminal y política social en el Estado de Derecho, in Romeo Casabona (ed.), Presupuestos para la reforma penal, I, LagunaTenerife, 1992, $69 \mathrm{ff}$.

${ }^{92}$ See Ferreiro Baamonde, La víctima en el proceso penal, Madrid, 2005, $5 \mathrm{ff}$.

93 Silva Sánchez, Medios no judiciales de reparación a la victima, in Romeo Casabona (ed.), Responsabilidad penal y responsabilidad civil de los profesionales. XXII coloquio de derecho europeo, La Laguna, 1993, $331 \mathrm{ff}$.

${ }_{94}$ SilvaSánchez, La consideración del comportamiento de la víctima en la teoría jurídica del delito. Observaciones doctrinales y jurisprudenciales sobre la "victimo-dogmática", AA.VV., La Victimología. Cuadernos de Derecho Judicial, Madrid, 1993, $11 \mathrm{ff}$.

${ }^{95}$ Fletcher, The grammar of criminal law: american, comparative and international, I, Foundations, Oxford, 2007, $255 \mathrm{ff}$.

${ }^{96}$ ContraHassemer/Reemtsma, Verbrechensopfer,62. 
victims). This explains why very few Americans have declared that the U.S. antiterror legislation has affected their fundamental freedoms ${ }^{97}$ : the illegal wiretapping and interrogations, Guantanamo, the summary trial were and are targeted at a particular category of people (suspected terrorists), and not at all the others (potential victims of terrorists), in whose name, indeed, that war is fought.

\section{Résumé}

In my opinion the passionate quarrel on the conflict-harmony between freedom and security is but the conflict between the idea that criminal law must maintain its offender-centred vocation, and the idea that criminal law has completely lost any liberal feature and has become an instrument to protect the society of victims ${ }^{98}$.

Contrary to what has happened in continental criminal justice systems, where the victims, despite their 're-birth', have maintained a marginal position, Europe is going in the opposite direction: "its" criminal justice system, being designed to preserve and protect the interests and rights of the victims (of state agents, of private individuals, of crime, of process, potential, real, vulnerable, innocent, 'guilty'), marginalizes the offender.

${ }^{97}$ Cole, Enemy aliens. Double standards and constitutional freedoms in the war on terrorism, New York-London, 2003,18

${ }^{98}$ On this approach, see Gómez Martín, Libertad, segudidad y «sociedad del riesgo, in Mir Puig/Corcoy Bidasolo (eds.), La política criminal in Europa, Barcelona, 2004, 59 ff. 